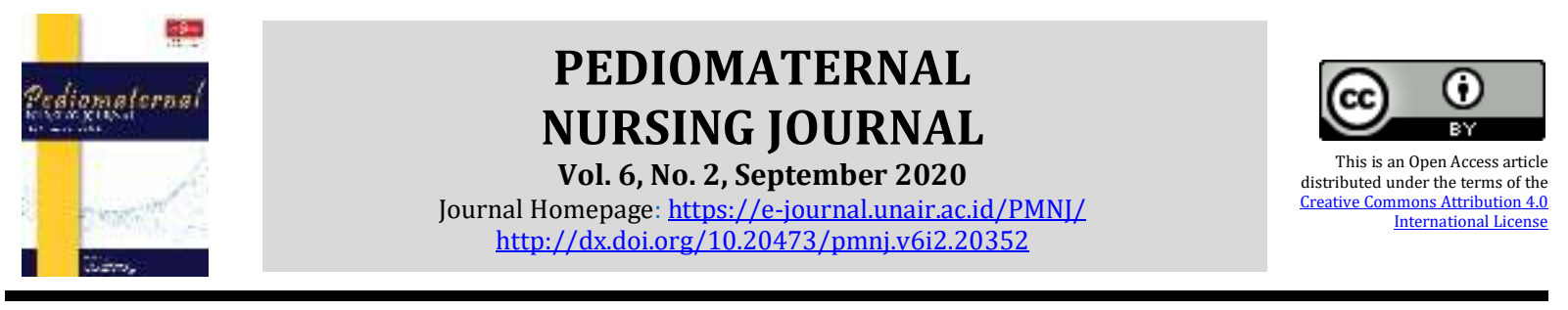

Original Research

\title{
The Comparison of Total Cholesterol Level in DMPA and Combination Injection Contraception Users
}

\author{
Rara Yumna Elfrida1 ${ }^{1}$, Gadis Meinar Sari ${ }^{2}$, Sri Ratna Dwiningsih ${ }^{3}$, Pudji Lestari ${ }^{4}$ \\ 1Midwifery Department, Faculty of Medicine, Universitas Airlangga, Surabaya Indonesia \\ 2Physiology Department, Faculty of Medicine, Universitas Airlangga, Surabaya Indonesia \\ 3Obstetrics and Gynecology Department, Faculty of Medicine, Universitas Airlangga, Surabaya Indonesia \\ ${ }^{4}$ IKM-KP Department, Faculty of Medicine, Universitas Airlangga, Surabaya Indonesia
}

\section{ARTICLE HISTORY \\ Received: June 30, 2020 \\ Accepted: July 22, 2020 \\ Published: Augustus 4, 2020 \\ KEYWORDS \\ hormonal injection contraception; DMPA users; lipid profile}

\section{CORRESPONDING AUTHOR}

Rara Yumna Elfrida rarayumna@gmail.com Midwifery Department, Faculty of Medicine, Universitas Airlangga, Surabaya Indonesia

Cite this as:

\begin{abstract}
Introduction: Hormonal injection contraception is the most widely used method of contraception in Indonesia. In long-term use, one of the side effects of injection contraception is changes in lipid metabolism in the body caused by the accumulation of hormones in the body. Two types of injectional contraception are widely used in Indonesia, namely combined injection and DMPA injection; different hormonal content has various side effects on the lipid profile. This study aimed to compare the total cholesterol level between acceptors of DMPA injection and combined injection.
\end{abstract}

Methods: This study used an observational analytic method with a crosssectional approach. The sample size is 60 respondents, including 30 DMPA injection acceptors and 30 combination injection acceptors. The sampling method uses a purposive sampling technique The independent variable in this study was the total cholesterol level of the acceptor, and the dependent variable was the acceptor of DMPA injection and the combination injection acceptor. Analysis of research data used the Independent T-test with $\alpha=0.05$.

Results: The results of the bivariate analysis found significant differences in total cholesterol levels in the DMPA injection contraception acceptor and combination injection with $\mathrm{p}=0.037$. It was found that overall cholesterol levels of DMPA injection acceptors were higher.

Conclusion: There is a difference in total cholesterol levels in the DMPA injection contraception acceptor with a combination injection contraception acceptor.

Elfrida, R, Y., Sari, G, M., Dwiningsih, S, R., \& Lestari, P. (2020). The Comparison of Total Cholesterol Level in DMPA and Combination Injection Contraception Users. Pediomaternal Nurs. J., 6(2), 117-124. Doi: http://dx.doi.org/10.20473/pmnj.v6i2.20352

\section{INTRODUCTION}

Indonesia is a developing country with a population of 262 million people with an average population density of 138.49 people $/ \mathrm{km}^{2}$. In the context of equal distribution of population, the government implements several methods, one of them is controlling the population by reducing the 
number of births through family planning or delaying the age of first marriage (Kementrian Kesehatan RI, 2019). Active family planning acceptors in Indonesia in fertile age couples in 2018 amounted to 63.27\% (Kemenkes RI, 2018). The most extensive coverage of active family planning participants was contraceptive injection acceptors, amounting to $63.71 \%$. In Surabaya, it was also found that people were more fond of contraceptive injection by 64.7\% (Profil Kesehatan Kota Surabaya, 2018).

Hormonal injection contraception remains as a contraceptive method with the highest interest due to its wide variations, high effectiveness, easy access, and less invasive risk. Hormonal injection contraception marketed in Indonesia is available in 2 types, namely 3-monthly contraceptive injection with $150 \mathrm{mg}$ of Depo Medroxyprogestine Acetate and monthly injection method, a combined contraceptive injection of $25 \mathrm{mg}$ Depo Medroxyprogestine Acetate and $5 \mathrm{mg}$ Estradiol Cypionate (Affandi, 2014). In combined injection contraceptives user shows that the estrogen hormone contained in it can balance hormones in the body, thereby minimizing the side effects caused by DMPA.

In the long-term use of progesterone contraception, some changes in lipids serum, headaches, and decreased libido can occur (Sulistyawati, 2014). Combined contraception has side effects such as irregular menstrual patterns, heart attacks, strokes, blood clots, hyperlipidemia, weight gain. Hormonal contraception can also affect fat metabolism, especially lipoproteins (Speroff, 2011).

The contraceptive injection is not recommended for usage for more than two years in a row due to hormonal imbalances that can interfere with the function of organs in the body (BKKBN, 2015). Long-term use of progesterone can trigger an increase in LDL level and a decrease in HDL level (Katzung, 2016). These changes begin to appear significantly in usage for over 12 months (Dilshad et al., 2016).

The abnormal levels can be a trigger for increased cardiovascular disease. The number one cause of death in Indonesia is caused by cardiovascular disease, with the number 36.3\% (Institute of Health Metrics, 2016). One of the most common cardiovascular diseases in Indonesia is a stroke. Stroke morbidity rates in Indonesia increased from 1.7\% in 2013 to 7\% in 2018 (Riskesdas, 2018). A similar study conducted in Harar Ethiopia found the total cholesterol $>200 \mathrm{mg} / \mathrm{dl}$ of $33.7 \%$ and average total cholesterol of $186 \mathrm{mg} / \mathrm{dl}$ (Asare, 2019). Abnormal cholesterol levels in Indonesian women are higher than men in the amount of $39.6 \%$, and men were found in $30 \%$ (Riskesdas, 2013).

Based on the description above, this research needs to be done to determine differences in cholesterol levels in the combination and DMPA injection contraception acceptor. This research is expected to be one of the references in determining the choice of contraception.

\section{METHOD}

\subsection{Design}

This research was an analytic observational study and conducted with a cross-sectional approach.

\subsection{Population, Samples, and Sampling}

This research was done in Bulak Banteng Primary Health Care's working area. The research population was the entire DMPA and Combination Injection contraception acceptors in Bulak Banteng Primary Health Care with a total of 60 samples with details of 30 samples per group. Sampling was conducted through a purposive sampling technique. The subjects taken are those who meet the inclusion and exclusion criteria. Inclusion criteria in this study were respondents with reproductive age of 15-40 years and had not experienced symptoms of menopause, the use of injection contraceptive for at least 12 months with regular use and without using any other contraceptives this was obtained from the respondent's Family Planning (FP) register, had a normal BMI (18.5- $29.9 \mathrm{~kg} / \mathrm{m} 2$ ) at the last examination seen from the FP register, and agreed to sign the informed consent. At the same time, the exclusion criteria in this study are those who have a history of dyslipidemia, diabetes mellitus, hypertension level I (systole> 140mmhg), chronic kidney 
failure, coronary heart disease, smoking, and alcohol consumption. Blood pressure examination is referred from the last examination on the FP register, while other data are obtained from the anamnesis.

\subsection{Variables}

Independent variables are DMPA and Combined injection contraception acceptor with nominal data scale. Dependent variables were the acceptor's total cholesterol level.

\subsection{Instruments}

Acceptor's cholesterol level with the ratio scale is measured by electrode-based biosensor with an EasyTouch CGU tool that has $<10 \%$ bias by using it less than 100 times to ensure its validity.

\subsection{Procedure}

The researcher always obeys the regulations to make sure the research conducted legally by asking permission to the faculty, BANGKESBANGPOL (National unity, Politics, and Community Protection Agency) Surabaya and Surabaya Public Health Service. This research used primary data, which is the respondent's total cholesterol level examination result. Blood is drawn from the capillary blood at the fingertips. Blood specimens placed directly on cholesterol sticks, and the examination results can be directly obtained within $90-120$ seconds. The researcher searched for the respondent that met the criteria from the contraception cohort and did a home visit accompanied by Bulak Banteng Primary Health Care's cadre. Samples are chosen by using a purposive sampling technique.

Respondents that matched the criteria are later given an explanation about the research and informed consent. After the respondents gave the approval, they are required to do fasting for 9-12 hours before their blood samples were taken to prevent confounding from the food consumed.

\subsection{Analysis}

This research analysis includes univariate and bivariate analysis. The univariate analysis contains distributions of respondents' general data frequency, which are age, last education, number of children, contraception period of use, and normality test are done by using the Kolmogorov Smirnov test. The parametric independent Ttest is used for bivariate analysis with $\alpha=0.05$ because both group data have a normal distribution.

\subsection{Ethical Clearance}

This research was conducted after getting the ethical clearance approval from the ethics committee of Medicine Faculty of Universitas Airlangga in March 2020 with the number 76/EC/KEPK/FKUA2020. This research beholds three ethics principles which are informed consent, anonymity, and confidentially.

\section{RESULT}

Based on table 1, the distribution frequency of respondent's last education is mostly elementary school (43.4\%) in DMPA injection and junior high school (40\%) in combined injection. The age frequency distribution of the two acceptors is mostly at the age of 2035 years. The highest number of children in both acceptors was $<2$ with a DMPA injection by $74.4 \%$ and combined injection by $83.3 \%$. The duration of contraception usage in DMPA injection users was mostly at 36-47 months by $40 \%$ and for the combined injection users at 24-35 months usage by $33.4 \%$.

The results showed based on table 2 that the DMPA injection acceptor had a lower normal level of cholesterol, which was $56.7 \%$ compared to the combined injection of $73.3 \%$. In the acceptor, it was found that abnormal cholesterol was higher at $13.3 \%$ compared to combined ones of only $6.7 \%$. The mean total cholesterol level in DMPA injection was also higher, namely $199.57 \pm$ $34.208 \mathrm{mg} / \mathrm{dL}$ compared to the combined injection, which was only $180.30 \pm 35.509$ $\mathrm{mg} / \mathrm{dL}$. Statistical testing using the Independent T-test parametric comparative test showed $\mathrm{p}=0.037$ indicating a significant difference in the total cholesterol level of DMPA and combined contraceptive injection acceptors.

\section{DISCUSSION}

In the results of the study, it was found that there were significant differences in cholesterol levels between the two acceptors with $\mathrm{p}<0.05$. Contraceptive injection, which 
Table 1. Characteristic Respondents ( $\mathrm{n}=60)$

\begin{tabular}{|c|c|c|c|c|}
\hline \multirow{2}{*}{ Characteristic } & \multicolumn{2}{|c|}{ DMPA } & \multicolumn{2}{|c|}{ Combination } \\
\hline & $\mathbf{n}$ & $\%$ & $\mathbf{n}$ & $\%$ \\
\hline \multicolumn{5}{|l|}{ Age } \\
\hline $20-35$ & 27 & 90 & 26 & 86.6 \\
\hline$>35$ & 3 & 10 & 4 & 14.4 \\
\hline \multicolumn{5}{|l|}{ Last Education } \\
\hline Elementary School & 13 & 43.4 & 7 & 23.3 \\
\hline Junior high School & 6 & 20 & 12 & 40 \\
\hline Senior High School & 10 & 33.3 & 10 & 33.3 \\
\hline College & 1 & 3.3 & 1 & 3.3 \\
\hline \multicolumn{5}{|l|}{ Number of Children } \\
\hline$\leq 2$ & 22 & 73.4 & 25 & 83.3 \\
\hline$>2$ & 8 & 26,6 & 5 & 16.7 \\
\hline \multicolumn{5}{|l|}{ Duration of Use } \\
\hline 12-23 Months & 4 & 13.3 & 6 & 20 \\
\hline 24-35 Months & 11 & 36.7 & 10 & 33.4 \\
\hline 36-47 Months & 12 & 40 & 7 & 23.3 \\
\hline 48-60 Months & 3 & 10 & 7 & 23.3 \\
\hline
\end{tabular}

Table 2. The Comparison of total cholesterol level in DMPA and combined injection contraception

Total Cholesterol Level

\begin{tabular}{|c|c|c|c|c|c|c|c|c|}
\hline \multirow[t]{2}{*}{$\begin{array}{l}\text { Contraceptional } \\
\text { Injection }\end{array}$} & \multicolumn{2}{|c|}{$\begin{array}{c}\text { Normal } \\
(<200 \mathrm{mg} / \mathrm{dL})\end{array}$} & \multicolumn{2}{|c|}{$\begin{array}{c}\text { Borderline High } \\
\text { (200mg/dL-240 } \\
\text { mg/dL) }\end{array}$} & \multicolumn{2}{|c|}{$\begin{array}{c}\text { High } \\
(>240 \mathrm{mg} / \mathrm{dL})\end{array}$} & \multirow[t]{2}{*}{ Mean \pm SD } & \multirow[t]{2}{*}{$\mathbf{P}$} \\
\hline & $\mathbf{n}$ & $\%$ & $\mathbf{n}$ & $\%$ & $\mathbf{n}$ & $\%$ & & \\
\hline DMPA & 17 & 56.7 & 9 & 30 & 4 & 13.3 & $199.57 \pm 34.208$ & \multirow{3}{*}{0.037} \\
\hline Combination & 22 & 73.3 & 6 & 20 & 2 & 6.7 & $180.30 \pm 35.509$ & \\
\hline Total & 39 & 65 & 15 & 25 & 6 & 10 & $189.93 \pm 35.907$ & \\
\hline
\end{tabular}

is a method of inserting hormones at a high dose into the body in one injection (Marmi, 2016). Contraception that contains steroid hormones that will be metabolized in the liver, and its accumulation will interfere with the liver function (Farmakologi UI, 2016). Frequency distribution on the characteristics of the duration of contraceptive used by respondents found that most respondents on DMPA injection and combined injection have used injection contraception for 24-35 months of use with a percentage of $35 \%$ among the total acceptors. Research in Pakistan shows an increase in the average of total cholesterol levels of $\pm 47 \mathrm{mg} / \mathrm{dL}$ in hormonal contraceptive users at 12 months of use (Dilshad et al., 2016). The hormonal contraceptive injection is not recommended for the use of more than two years in a row because there can be a hormonal imbalance that can interfere with the function of organs in the body (BKKBN, 2015).

Based on the research results, the average total cholesterol level in the DMPA injection acceptors is higher than in the combined injection, as much as $199.57 \pm 34,208 \mathrm{mg} / \mathrm{dL}$ in the DMPA injection acceptor and $180.30 \pm$
$35.509 \mathrm{mg} / \mathrm{dL}$ in the combined injection acceptor. The frequency of respondents with borderline-high and high was also more often found in the DMPA injection acceptor that is $43.3 \%$ or as many as 13 respondents and abnormal cholesterol levels of $26.7 \%$ or as many as 8 respondents in the combined injection acceptors.

Total cholesterol levels in DMPA contraceptive acceptors (progesterone) are higher than combined contraceptive users (estrogen and progesterone) caused by the suppression of the estrogen hormone in DMPA contraceptive acceptors affect the decrease in endogenous estrogen hormones suppress lipase activity in the liver (Randolph et al., 2011; Berg et al., 2004). Suppression of endogenous estrogen levels inhibits the action of the ACAT enzyme, which can inhibit cholesterol synthesis by the HMG CoA Reductase enzyme, which results in elevated LDL levels and increases hepatic lipase enzymes causing increased HDL breakdown and resulted in the decrease of HDL levels (Kavanagh et al., 2009). Estrogen signals the regulation of HDL absorption and secretion from the macrophages (Della et al., 2016). 
Estrogen plays a role in suppressing the synthesis of IDL and LDL, increasing HDL synthesis, increasing lipoprotein metabolism, minimizing exposure to oxidative stress and remodeling. Estrogen also plays a role in lipid metabolism in arterial walls by reducing LDL penetration and retention, increasing and recovering nitric oxide for arterial vasodilation, and reducing arterial wall damage (Palmisano et al., 2018). Decreasing HDL in DMPA contraceptive users causes LDL levels to increase. That is because the function of HDL is to break down triglycerides and LDL to be re-synthesized in the liver, thereby reducing the attachment of plaque in blood vessel walls (Menazza, 2016). Increased LDL and decreased HDL have a significant effect on increasing total cholesterol levels (Murray, 2016). This causes combined contraceptive users to have relatively stable cholesterol levels compared to DMPA contraception due to combined contraceptives containing Ethynil Estradiol that balances the hormonal level in the body (Astuti et al., 2018).

The results of the study, according to statistical tests, show that the cholesterol level data in the DMPA injection and combined contraceptive injection showed normal distribution. I was testing the results of the study using the Independent T-Test with the results of $p=0.037$, which indicates that there is a significant difference in the total cholesterol level of the DMPA injection acceptors with the total cholesterol level in the combined injection acceptor. These results second to several similar studies. Research conducted in Harar found that acceptors of DMPA injection had higher total cholesterol levels than other contraceptives in the amount of $189.35 \mathrm{mg} / \mathrm{dL} \pm 20 \mathrm{mg} / \mathrm{dL}$ (Sufa et al., 2019). According to the research conducted in Pakistan on the comparison between DMPA injection acceptors and the control group showed the results of DMPA total cholesterol levels of $180.7 \pm 38.8 \mathrm{mg} / \mathrm{dL}$ and the controls of $133.03 \pm 14.8 \mathrm{mg} / \mathrm{dL}$ with the statistical results $p=0.001$ which shows that there are very significant differences in cholesterol levels in each group (Dilshad et al., 2016). Research conducted on experimental animals given DMPA injections showed an increase in total cholesterol levels, known that the initial total cholesterol level before injection was $115.62 \mathrm{mg} / \mathrm{dL}$ to 158.11 $\mathrm{mg} / \mathrm{dL}$ after the 6th week after injection (Bakry et al., 2010).

The results of the statistical test showed that there was a significant difference. This was following the research hypothesis that there was an increase in cholesterol levels in the DMPA injection acceptor. However, in the research conducted in Texas, the highest increase in total cholesterol was experienced by combined contraceptive acceptors with $\mathrm{p}$ $<0.001$ (Berenson et al., 2009). According to the research by Okeke et al. (2011) showed that there are significant differences in triglyceride and LDL levels in hormonal contraceptive acceptors. However, no significant differences were found in changes in total cholesterol and HDL levels (Okeke et al., 2011). Research conducted at Andalas and Lubuk Buaya Primary Health Care shows that total cholesterol levels in DMPA injections are higher than combined contraceptives. Still, statistically, no significant differences were found $(p=0.49)$ in both groups (Sitinjak et al., 2019).

Changes in serum lipids can affect the increase in total cholesterol and body metabolism. This can cause metabolic diseases such as dyslipidemia, stroke, venous thromboembolism, myocardial infarction, hypertension, and many other metabolic diseases (Perkeni, 2015). According to the research in Harar regarding the risk of dyslipidemia in hormonal contraception acceptors shows that in the contraceptive injection acceptors with a duration of 6-42 months, it was found that 33\% of acceptors were diagnosed with dyslipidemia. It is also influenced by the length of use of contraception. In the users with a duration of $>42$ months, there are $75 \%$ of users identified as dyslipidemia (Sufa et al., 2019).

A systematic review referring to the journal by Tanis et al. (2001) in the Netherlands shows that there is a significant increase in the risk of myocardial infarction in the combined contraceptive acceptors compared to non-acceptors (Dragoman et al., 2016). Another study conducted in Bangladesh found similar results with 70.4\% of hormonal contraception users identified as dyslipidemia compared to the non-hormonal contraceptive acceptors by $29.6 \%$, there was a significant difference with $\mathrm{p}=0.009$ 
(Sultana et al., 2016). Research conducted at Leyangan Primary Health Care shows that there is a significant relationship between the use of contraceptive injection and the increase in blood pressure with a value of $p=$ 0.037 (Widyaningsih et al., 2019). It is due to the exogenous estrogen, which can initiate an increase in blood pressure and stroke, that is contained in the combined hormonal contraception (Chiu et al, 2012).

The highest contraceptive acceptor in the working area of the Bulak Banteng Primary Health Care is the injection contraception acceptor, with a percentage of $95.4 \%$. The population in the working area of the Bulak Banteng Primary Health Care tend to have a high level of fear of invasive medical actions. Most respondents refused to use the longlasting form of contraception (metode kontrasepsi jangka panjang/MKJP) due to the excessive fear of the actions they received. Counseling on the various types of contraception has often been done by cadres and the primary health care staff. In order to increase the use of MKJP in the area, the Primary Health Care provides a facility for putting the MKJP at no charge and provides incentives for people who want to assign for sterilization. However, this still does not increase public enthusiasm regarding the MKJP.

In this study, it was found that there were significant differences in total cholesterol levels in the DMPA injection acceptor and the combined injection acceptor. Where cholesterol levels in DMPA injection are higher. Changes in cholesterol levels are not only influenced by hormonal. Abnormalities the individual lipid profile are very dependent on the lifestyle, food consumed, history of metabolic diseases. Injection contraception is safe to be used by always having a periodic screening and limiting the period of usage. Women of childbearing age are expected to consult with health workers before choosing the right method of contraception. Choosing the right contraception method must be carried out along with the appropriate screening in various aspects so that the benefits of contraception are achievable without causing adverse effects in the long-term use.

Weight and blood pressure criteria are not carried out directly. Data have seen from the respondent's contraception register so that it is not known with certainty if there is a change during the inspection. The examination of the photometer is judged to be higher insensitivity. The examination of cholesterol levels is only done by examination of sticks due to limited time, energy, and research permission. No initial cholesterol levels are known before contraceptive use, so it is not known with certainty whether there has been an increase or not.

\section{CONCLUSION}

There is a significant difference in FP contraception cholesterol levels in DMPA injection and combination injection. Women of childbearing age who use hormonal injection contraception are expected to routinely conduct counseling and screening to health workers in the selection of contraceptive methods. Injectable contraception is safely used if monitoring after first usage and advice to medical workers are done. It is not recommended for long period usage, and routine medical checkup needs to be done. For further research is still needed to prove the effect of long period usage.

\section{ACKNOWLEDGEMENT}

The researchers would like to thank all respondents who are willing to participate in this study. Thank you to all the KIA-KB TEAM and the FP Cadre of the Surabaya Bulak Banteng Health Center, who have helped with this research.

\section{CONFLICT OF INTEREST}

None.

\section{REFERENCES}

Affandi, B. (2014). Buku Panduan Praktis Pelayanan Kontrasepsi. jakarta: Bina Pustaka Sarwono Prawirohardjo.

Bakry, S., Hassan, A. M., Shahat, M. M. A., \& Abdullah, A. (2010). Effect of DepoProvera on Estrous Cyclicity, Serum Proteins and Lipid Profile in Mice. World Applied Sciences Journal, 8(9), 10421049. 
Berenson, A. B., Rahman, M., Wilkinson, G., \& Ma, F. A. C. E. (n.d.). Effect of injectable and oral contraceptives on serum lipids. https://doi.org/10.1097/A0G.0b013e3 181b76bea

Berg, G., Mesch, V., Boero, L., Sayegh, F., Prada, M., Royer, M., ... Benencia, H. (2004). Lipid and lipoprotein profile in menopausal transition. Effects of hormones, age and fat distribution. Hormone and Metabolic Research, 36(4), 215-220. https://doi.org/10.1055/s2004-814450

BKKBN. (2015). Jangan Sembarang Memilih Kontrasepsi. Retrieved from www.bkkbn.go.id

Della Torre, S., Mitro, N., Fontana, R., Gomaraschi, M., Favari, E., Recordati, C., ... Maggi, A. (2016). An Essential Role for Liver ER $\alpha$ in Coupling Hepatic Metabolism to the Reproductive Cycle. Cell Reports, 15(2), 360-371. https://doi.org/10.1016/j.celrep.2016.0 3.019

Departemen Farmakologi dan Terapeutik FK UI. (2014). Farmakologi dan Terapi (6th ed.). Jakarta: Bagian Farmakologi FK UI.

Dilshad, H., Ismail, R., Naveed, S., Usmanghani, K., Alam, M. T., \& Sarwar, G. (2016). Effect of hormonal contraceptives on serum lipids: A prospective study. Pakistan Journal of Pharmaceutical Sciences, 29(4), 13791382.

Dinas Kesehatan Kota Surabaya. (2019). Profil Kesehatan Kota Surabaya tahun 2018. Surabaya.

Dragoman, M., Curtis, K. M., \& Gaffield, M. E. (2016). Combined hormonal contraceptive use among women with known dyslipidemias: a systematic review of critical safety outcomes. Contraception, 94(3), 280-287. https://doi.org/10.1016/j.contraceptio n.2015.08.002

Katzung B, G. (2014). Farmakologi Dasar \& Klinik (12th ed.). Jakarta: EGC.

Kemenkes RI. (2018). Riset Kesehatan Dasar tahun 2018, RISKESDAS. Jakarta:
Balitbang Kemenkes RI.

Kementrian Kesehatan RI. (2019). Profil Kesehatan Indonesia 2018. Jakarta: Kemenkes RI.

Menazza, S., \& Murphy, E. (2016). The Expanding Complexity of Estrogen Receptor Signaling in the Cardiovascular System. 994-1007. https://doi.org/10.1161/CIRCRESAHA. 115.305376

Murray, R. . (2014). Biokimia Harper (29th ed.). Jakarta: Buku Kedokteran ECG.

Okeke, C. U., Braide, S. A., Okolonkwo, B. N., Okafor, R., Eneh, P. C., Adegoke, A., ... Okwandu, N. B. (2011). Comparative Effects of Injectable and Oral Hormonal Contraceptives on Lipid Profile. European Journal of Cardiovascular Medicine Vol, II(I), 20-22. https://doi.org/10.5083/ejcm.2042488 4.64

Palmisano, B. T., Zhu, L., Stafford, J. M., \& Affairs, V. (2018). Estrogens in the Regulation of Liver Lipid Metabolism. (615). https://doi.org/10.1007/978-3319-70178-3

Randolph, J. F., Zheng, H., Sowers, M. F. R., Crandall, C., Crawford, S., Gold, E. B., \& Vuga, M. (2011). Change in folliclestimulating hormone and estradiol across the menopausal transition: Effect of age at the final menstrual period. Journal of Clinical Endocrinology and Metabolism, 96(3), 746-754. https://doi.org/10.1210/jc.2010-1746

Sitinjak, H. L. (2019). Perbedaan Kadar Trigliserida dan Indeks Massa Tubuh Antara Akseptor Pil Kombinasi dengan DMPA. Jurnal Endurance, 4(2), 335. https://doi.org/10.22216/jen.v4i2.394 2

Speroff, L., \& D, D. P. (2011). A clinical guide for contraception (5th ed.). Philadelphia: Lippincott Williams \&Wilkins.

Sufa, B., Abebe, G., \& Cheneke, W. (2019). Dyslipidemia and associated factors among women using hormonal contraceptives in Harar town, Eastern Ethiopia. BMC Research Notes, 12(1), 
120. https://doi.org/10.1186/s13104019-4148-9

Sulistyawati, A. (2014). Pelayanan Keluarga Berencana. Jakarta: Salemba Medika.

Sultana, A., Khatun, K., \& Alam, A. M. M. (2017). Duration of Oral Contraceptives Use and Risk of Development of Dyslipidemia among Women in Dhaka City. Journal of Science Foundation,
$14(2)$

40-43.

https://doi.org/10.3329/jsf.v14i2.3344

3

Widyaningsih, A., \& Isfaizah, I. (2019). Hubungan Kontrasepsi Hormonal Terhadap Tekanan Darah Di Puskesmas Leyangan Tahun 2018. Indonesian Journal of Midwifery (IJM), 2(1), 5-10. https://doi.org/10.35473/ijm.v2i1.143 